\title{
Sjögren-Larsson syndrome
}

INSERM

\section{Source}

INSERM. (1999). Orphanet: an online rare disease and orphan drug data base. SjögrenLarsson syndrome. ORPHA:816

Sjögren-Larsson syndrome (SLS) is a neurocutaneous disorder caused by an inborn error of lipid metabolism and characterized by cong enital ichthyosis, intellectual deficit, and spasticity. 